\title{
Level of Factors Effects on Customers' Satisfaction of State Health Insurance in Developing Countries: The Case of Vietnam
}

\author{
Nguyen Thi Hai Duong* Nguyen Thi Chinh $\quad$ Nguyen Xuan Tiep Le Quy Duong Bui Quynh Anh \\ Faculty of Insurance, National Economics University, 207 Giai Phong Road, Hanoi, Vietnam
}

\begin{abstract}
The article aims to assess the level of factors effecting on customer's satisfaction with The State Health Insurance, study the case of Vietnam. Parasuraman's SERVQUAL model is utilized to measure the influence of five factors on the customers' satisfaction with the Vietnam's State Health Insurance. Five factors are (1) Tangibles, (2) Reliability, (3) Empathy, (4) Assurance and (5) Responsiveness. The data is surveyed by questionnaire by sampling selection method from three Vietnamese largest cities with a total of 764 respondents. Based on the results of Exploratory Factor Analysis (EFA) and multiple regression analysis, five factors have positive effects on the customers' satisfaction. The level of responsiveness effect is highest, whereas the level of empathy effect is lowest. This empirical result demonstrates that the service quality is essential to create high customers' satisfaction with The State Health Insurance although it is compulsory for all Vietnamese citizens. Improving service quality is the key to maintain a high covered rate of state health insurance, which contributes to ensuring social security.
\end{abstract}

Keywords: customer's satisfaction, The State Health Insurance.

DOI: $10.7176 / \mathrm{JESD} / 10-24-08$

Publication date: December $31^{\text {st }} 2019$

\section{Introduction}

Health insurance is an important tool to ensure financial resource to pay for medical expenses. Despite being a developing country, Vietnam has made great efforts to achieve universal health insurance with the goal of increasing the covered rate to $90 \%$ by 2020 . At the end of $2018,88.5 \%$ Vietnamese population, which is equivalent to 83.5 million people, are covered by the State Health Insurance. The proportion of out-of-pocket expenditure on healthcare decreases considerably from 63\% during 1995-2014 period to 37\% in 2017 (WDI, 2017). However, since the national healthcare system is overloaded, a great number of customers covered by the state health insurance are not well-treated. Various citizens paying the state health insurance premium have a tendency to use private healthcare services. Many people do not renew the state health policy or have a negative attitude towards state health insurance.

Given this backdrop, assessing level of factors effecting on customer's satisfaction with Vietnamese state health insurance is extremely necessary in order to improve the quality of state health insurance services, which creates the favorable conditions for Vietnam to achieve universal health insurance in 2020.

\section{Literature review}

Numerous studies have been conducted to clarify the relationship between service quality and customer satisfaction in the service sector. To measure consumer' perception of service quality in service and retailing organizations, Parasuraman et al. (1988) developed the SERVQUAL model, which includes five dimensions: Tangibles, Reliability, Responsiveness, Assurance and Empathy. Cronin and Taylor (1992) stated that service quality should be measured as an attitude. Their SERVPERF model is a performance-based approach to measure the service quality, while the SERVQUAL model is based on the concept of service quality as the difference between the client's perceived performance and expectation. However, dimensions of both models are nearly the same. Later on, although various models have been developed to measure the service quality such as RSQS model (Dabholkar et al., 1996), INTSERVQUAL model (Frost \& Kumar, 2000), Service Quality model (Brady \& Cronin, 2001), etc. , SERVQUAL is the most commonly used conceptual model for studying and analyzing the quality of services (Emel Kursunluoglu, 2014).

Based on the SERVQUAL model and an extensive review of literature on healthcare service quality, Yogesh and Satyanarayana (2012) build an instrument measuring the patient's viewpoint of healthcare quality. It includes ten dimensions: Physical Environment and Infrastructure, Personnel Quality, Image, Trustworthiness, Support, Process of Clinical Care, Communication, Relationship, Personalization and Administrative Procedures. However, the main limitation of this research is that there is no data sample to test the significance of each dimension. Its instrument is created by reviewing previous studies rather than analyzing empirical data.

Nguyen Thi Nhu Quynh and Neera Dhar (2014) assess the satisfaction of poor patients holding the health insurance cards with the healthcare services in two public hospitals in Vietnam. There are 195 patients who complete questionnaires. The results show that poor patients are not really satisfied with the procedures prior to treatment, particularly the waiting time for registration and examination. However, the authors only use the 
descriptive analysis to assess satisfaction and do not build a model to measure the level of factors effecting on patients' satisfaction.

Expanding the SERVQUAL model, Lee (2016) develops the HEALTHQUAL model to measure the quality of medical services in Korea. There are five factors: Empathy of physicians and medical staff (Empathy), Hospital facilities (Tangible), Qualification of physicians (Staff qualification), Quality of medical examinations and treatments (Efficiency quality) and Reliability. The data sample includes 385 inpatient patients and 251 outpatient patients at a hospital in Korea. The result of the explanatory factor analysis shows that all factors are significant. Particularly, Staff qualification and Efficiency quality are the most influences on the customer' satisfaction with the quality of medical services.

Connected with the SERVQUAL paradigm, Toni Lupo (2016) builds a framework to evaluate the quality of public hospital service in Sicily, Italia. From the analysis result, six key factors affecting the healthcare service quality is identified. They are Tangibles, Healthcare Staff, Responsiveness, Accessibility, Support Service and Reliability. Toni Lupo (2016) pointed out that the two most essential factors are Healthcare Staff and Responsiveness.

\section{Research design and hypotheses}

\subsection{Research design}

Based on the characteristics of Vietnam's State Health Insurance and previous papers regarding the relationship between service quality and customer' satisfaction in healthcare and insurance service, authors propose the research design as follows. The service quality of the State Health Insurance is a combination of five dimensions: Tangibles, Reliability, Empathy, Assurance and Responsiveness.

\begin{tabular}{|c|c|c|c|}
\hline \multirow{4}{*}{$\begin{array}{c}\text { The } \\
\text { service } \\
\text { quality of } \\
\text { The State } \\
\text { Health } \\
\text { Insurance }\end{array}$} & 1. Tangibles & \multirow{5}{*}{$\begin{array}{c}\text { Customer' } \\
\text { satisfaction with } \\
\text { The State } \\
\text { Health } \\
\text { Insurance }\end{array}$} & \multirow{5}{*}{$\begin{array}{c}\text { Control } \\
\text { variables: } \\
\text { Gender, } \\
\text { Income, } \\
\text { Age, } \\
\text { Occupation }\end{array}$} \\
\hline & 2. Reliability & & \\
\hline & 3. Empathy & & \\
\hline & 4. Assurance & & \\
\hline & 5. Responsiveness & & \\
\hline
\end{tabular}

Figure No. 1: Research Design

Source: Based on SERVQUAL model of Parasuraman et al. (1988)

\subsection{Hypotheses}

There are five proposed hypotheses in this research:

H1: There is a positive linkage between tangibles and customer' satisfaction with The State Health Insurance.

H2: There is a positive linkage between reliability and customer' satisfaction with The State Health Insurance.

H3: There is a positive linkage between empathy and customer' satisfaction with The State Health Insurance.

H4: There is a positive linkage between assurance and customer' satisfaction with The State Health Insurance.

H5: There is a positive linkage between responsiveness and customer' satisfaction with The State Health Insurance.

\section{Methodology}

This study used quantitative research method to evaluate the level of factors impact on customers' satisfaction of the State Health Insurance through etimating a linear regression model and statistical analysis. The below figure shows research framework: 


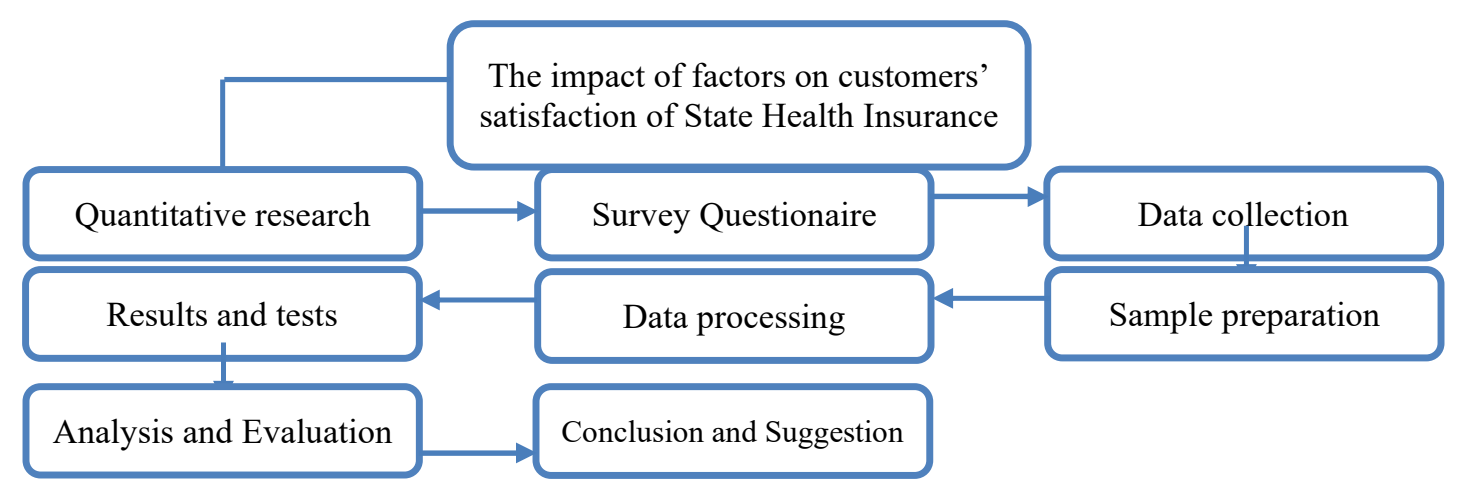

Figure No. 2: Research Framework

Source: Proposal of the authors

The data is collected by using survey questionnaires. Variables are measured by Likert scale (1932) with a typical five-level item: Strongly Dissatisfied, Dissatisfied, Neutral, Satisfied, and Strongly Satisfied. Likert scale is widely used in various studies of behavior, attitudes or satisfaction with healthcare and insurance services such as Lee (2016), Toni Lupo (2016), Pham Thi Dinh and Nguyen Thanh Vinh (2015), Nguyen Thi Nhu Quynh and Neera Dhar (2014), etc. According to Geoff (2010), thanks to applying Likert scale, responders are not forced to express an either-or opinion, which allows them to be neutral as their choice.

Data sample is obtained by using a simple random sampling selection method from three Vietnamese largest cities with a total of 764 respondents. These cities (Hanoi, Vinh and Ho Chi Minh) represent the biggest metropolitan areas in the North, Middle and South of Vietnam. According to Comrey and Lee (1992), statistically, a sample size of 500 provides significant results for explanatory factor analysis. Hence, the chosen sample size in this research is 764, which ensures the significance of explanatory factor analysis.

Table 1. Sample size

\begin{tabular}{|c|c|c|c|c|c|}
\hline & \multirow{2}{*}{ Area } & \multirow{2}{*}{ City } & \multirow{2}{*}{$\begin{array}{c}\text { Expected } \\
\text { (respondents) }\end{array}$} & Respondents & Proportion (\%) \\
\cline { 5 - 6 } & & & 250 & 251 & 32.8 \\
\hline 1 & North & Hanoi & 250 & 245 & 32.1 \\
\hline 2 & Middle & Vinh & 250 & 268 & 35.1 \\
\hline \multicolumn{2}{|r}{ Total } & South Chi Minh & 750 & 764 & 100.0 \\
\hline
\end{tabular}

\section{Analytical Results}

5.1. Reliability Analysis

Table 2. Reliability Statistics

\begin{tabular}{|l|l|c|c|}
\hline \multicolumn{1}{|c|}{ No. } & \multicolumn{1}{|c|}{ Construct } & Items & Cronbach's Alpha \\
\hline 1 & Responsiveness (RES) & 5 & .793 \\
\hline 2 & Assurance (ASSU) & 5 & .754 \\
\hline 3 & Reliability (REL) & 4 & .822 \\
\hline 4 & Empathy (EMP) & 4 & .853 \\
\hline 5 & Tangibles (TAN) & 5 & .752 \\
\hline
\end{tabular}

Source: compiled from analysis result of authors

The Cronbach's alpha reliability test has been used to identify the validity of items used in survey. According to Hendrickson et al (1993) and McGraw and Wong (1996) the alpha of a scale should be greater than .700 for items to be used together as a scale. Therefore minimum 0.700 coefficient alpha values accepted to finalize the item validity. As per shown in Table 2 shows that all dimensions have appropriate reliability.

\subsection{Exploratory Factor Analysis (EFA)}

$\mathrm{KMO}$ is an indicator to consider the appropriateness of EFA, exploratory factor analysis (EFA) is appropriate when $0.5 \leq \mathrm{KMO} \leq 1$ (Hair, Anderson, Tatham và William, 2006). Bartlett's test looks at the hypothesis of correlation between correlation variables. If the test is statistically significant $(\mathrm{sig} \leq 0.05)$, the observed variables are correlated with each other in the whole (Hoang Trong and Mong Ngoc, 2005, p.262). Additionally, norm of average variance extracted: the scale is accepted as total variance extracted $>$ or $=50$ and Eigenvalues $>1$ (Gerbing \& Anderson, 1988). 
Table 3. KMO and Bartlett's Test

Kaiser-Meyer-Olkin Measure of Sampling Adequacy.

\begin{tabular}{llr} 
Bartlett's Test of Sphericity & Approx. Chi-Square & 1957.538 \\
& Df & 261 \\
& Sig. & .000 \\
\hline
\end{tabular}

\begin{tabular}{llr} 
Bartlett's Test of Sphericity & Approx. Chi-Square & 1957.538 \\
& Df & 261 \\
& Sig. & .000 \\
\hline
\end{tabular}

Source: compiled from analysis result of authors

The result of table 3 shows that KMO coefficients is .778 between 0.5 and 1.0 , indicating that the factors analysis is appropriate and significance levels is .000 less than 0.05 is satisfactory statistical significance.

Table 4. Total Variance Explained

\begin{tabular}{|c|c|c|c|c|c|c|c|c|c|}
\hline \multirow[b]{2}{*}{ Com. } & \multicolumn{3}{|c|}{ Initial Eigenvalues } & \multicolumn{3}{|c|}{$\begin{array}{l}\text { Extraction Sums of Squared } \\
\text { Loadings }\end{array}$} & \multicolumn{3}{|c|}{$\begin{array}{l}\text { Rotation Sums of Squared } \\
\text { Loadings }\end{array}$} \\
\hline & Total & $\begin{array}{c}\% \text { of } \\
\text { Variance }\end{array}$ & Cumu. \% & Total & $\begin{array}{c}\% \text { of } \\
\text { Variance }\end{array}$ & Cumu. \% & Total & $\begin{array}{c}\% \text { of } \\
\text { Variance }\end{array}$ & Cumu. \% \\
\hline 1 & 4.371 & 19.866 & 19.866 & 4.371 & 19.866 & 19.866 & 3.859 & 17.543 & 17.543 \\
\hline 2 & 3.775 & 17.159 & 37.025 & 3.775 & 17.159 & 37.025 & 3.823 & 17.376 & 34.918 \\
\hline 3 & 3.431 & 15.597 & 52.621 & 3.431 & 15.597 & 52.621 & 3.117 & 14.170 & 49.088 \\
\hline 4 & 3.011 & 13.686 & 66.307 & 3.011 & 13.686 & 66.307 & 3.039 & 13.812 & 62.901 \\
\hline 5 & 2.064 & 9.383 & 75.690 & 2.064 & 9.383 & 75.690 & 2.814 & 12.790 & 75.690 \\
\hline 6 & .584 & 2.657 & 78.347 & & & & & & \\
\hline 7 & .576 & 2.616 & 80.963 & & & & & & \\
\hline 8 & .532 & 2.420 & 83.382 & & & & & & \\
\hline 9 & .478 & 2.171 & 85.554 & & & & & & \\
\hline 10 & .440 & 2.002 & 87.555 & & & & & & \\
\hline 11 & .364 & 1.654 & 89.209 & & & & & & \\
\hline 12 & .344 & 1.564 & 90.773 & & & & & & \\
\hline 13 & .332 & 1.511 & 92.284 & & & & & & \\
\hline 14 & .303 & 1.376 & 93.660 & & & & & & \\
\hline 15 & .260 & 1.181 & 94.840 & & & & & & \\
\hline 16 & .224 & 1.020 & 95.860 & & & & & & \\
\hline 17 & .219 & .994 & 96.855 & & & & & & \\
\hline 18 & .184 & .835 & 97.690 & & & & & & \\
\hline 19 & .154 & .700 & 98.390 & & & & & & \\
\hline 20 & .143 & .649 & 99.038 & & & & & & \\
\hline 21 & .127 & .579 & 99.218 & & & & & & \\
\hline 22 & .110 & .503 & 99.525 & & & & & & \\
\hline 23 & .084 & .382 & 100.000 & & & & & & \\
\hline
\end{tabular}

Extraction Method: Principal Component Analysis.

Source: compiled from analysis result of authors

The above result table 4 shows that if basing on Initial Eigenvalues's norm $>1$, there are five factors and it's also explained total variance extracted is $75.690 \%(>50 \%)$, the result met the requirement of norm Rotation Method: Authors used rotation method by Varimax Produce to minimize number of variances that have large coefficient at the same factor. After rotation, remove variables with factor loading less than 0.5 (according to Hair $\&$ et al (2006), factor loading is an indicator to ensure the practical significance of EFA and factor loading $>0.5$ is considered to be of practical significance). The table 5 explained a factor on the recognizing of variables with large coefficients at the same factor. 
Table 5. Rotated Component Matrix ${ }^{a}$

\begin{tabular}{|c|c|c|c|c|c|}
\hline & & & ponent & & \\
\hline & 1 & 2 & 3 & 4 & 5 \\
\hline REL5 & .751 & & & & \\
\hline REL1 & .726 & & & & \\
\hline REL2 & .684 & & & & \\
\hline REL3 & .647 & & & & \\
\hline REL4 & .575 & & & & \\
\hline RES5 & & .784 & & & \\
\hline RES4 & & .742 & & & \\
\hline RES1 & & .709 & & & \\
\hline RES3 & & .678 & & & \\
\hline RES2 & & .672 & & & \\
\hline TAN4 & & & .718 & & \\
\hline TAN2 & & & .704 & & \\
\hline TAN5 & & & .680 & & \\
\hline TAN3 & & & .674 & & \\
\hline TAN1 & & & .641 & & \\
\hline ASSU4 & & & & .767 & \\
\hline ASSU1 & & & & .749 & \\
\hline ASSU5 & & & & .745 & \\
\hline ASSU3 & & & & .732 & \\
\hline ASSU2 & & & & .721 & \\
\hline EMP3 & & & & & .669 \\
\hline EMP1 & & & & & .642 \\
\hline EMP2 & & & & & .635 \\
\hline EMP4 & & & & & .589 \\
\hline
\end{tabular}

\subsection{Descriptive Statistics}

Source: compiled from analysis result of authors

Table 6. Descriptive Statistics

\begin{tabular}{|l|r|r|r|r|r|}
\hline & \multicolumn{1}{|c|}{ N } & \multicolumn{1}{c|}{ Minimum } & Maximum & \multicolumn{1}{c|}{ Mean } & \multicolumn{1}{c|}{ Std. Deviation } \\
\hline ASSU & 764 & 1.75 & 5.00 & 4.2834 & .51655 \\
RES & 764 & 1.00 & 5.00 & 4.3924 & .48903 \\
REL & 764 & 1.67 & 5.00 & 4.1741 & .55963 \\
EMP & 764 & 2.00 & 5.00 & 4.1056 & .62866 \\
TAN & 764 & 1.00 & 5.00 & 4.3459 & .56976 \\
SHL & 764 & 1.00 & 5.00 & 4.2163 & .60477 \\
Valid N (listwise) & 764 & & & \\
\hline
\end{tabular}

Source: compiled from analysis result of authors

The below table 6 shows the descriptive statistics result. All variables have means greater than 4 , mean of Responsibility variable is the highest (4.3924), whereas Empathy variable has the lowest mean (4.1056). The lowest standard deviation is Assurance variable at 0.51655 and the highest one is Empathy at 0.62866 . From these results, it can be said that questionnaires must have received many "agree" or "very agree" assessments from respondents.

\subsection{Correlation analysis}

Correlation analysis has been conducted to verify the relationship among quantitative variables through correlation coefficient Pearson (r). The correlation coefficients in the table below show the relationship among variables is relatively reasonable in both direction and strength. Specifically, all correlation coefficient values are between 0.0 and 0.8 , and have both positive and negative signs which reflect either positive or negative relationship. The relationship between dependent and independent variables has meaning without abnormal signs. In addition, the strength of the correlation coefficients ensures that there is no multi-collinearity phenomenon occurs when using linear regression model. Therefore, other statistics could be used to verify the relationship among variables. 
Table 7. Correlation analysis

\begin{tabular}{|ll|r|r|r|r|r|r|}
\hline & & Satisfaction & \multicolumn{1}{c|}{ ASSU } & \multicolumn{1}{c|}{ RES } & \multicolumn{1}{c|}{ REL } & \multicolumn{1}{c|}{ EMP } & TAN \\
\hline Pearson & Satisfaction & 1.000 & .336 & .229 & .376 & .067 & .520 \\
& ASSU & .336 & 1.000 & -.015 & .113 & -.282 & .038 \\
& RES & .229 & -.015 & 1.000 & .050 & -.053 & .007 \\
& REL & .376 & .113 & .050 & 1.000 & -.096 & .064 \\
& EMP & .067 & -.282 & -.053 & -.096 & 1.000 & .090 \\
& TAN & .520 & .038 & .007 & .064 & .090 & 1.000 \\
\hline
\end{tabular}

\subsection{Analysis regression}

After analyzing correlations between variables then putting the appropriate independent variables into the regression equation by enter method through SPSS.

Table 8. Model Summary ${ }^{b}$

\begin{tabular}{|c|c|c|c|c|c|c|c|c|c|c|}
\hline \multirow[b]{2}{*}{ Model } & \multirow[b]{2}{*}{$\mathrm{R}$} & \multirow[b]{2}{*}{ R Square } & \multirow[b]{2}{*}{$\begin{array}{c}\text { Adjusted R } \\
\text { Square }\end{array}$} & \multirow{2}{*}{$\begin{array}{l}\text { Std. Error } \\
\text { of the } \\
\text { Estimate }\end{array}$} & \multicolumn{5}{|c|}{ Change Statistics } & \multirow[b]{2}{*}{$\begin{array}{l}\text { Durbin- } \\
\text { Watson }\end{array}$} \\
\hline & & & & & $\begin{array}{l}\text { R Square } \\
\text { Change }\end{array}$ & F Change & df1 & $\mathrm{df} 2$ & $\begin{array}{c}\text { Sig. F } \\
\text { Change }\end{array}$ & \\
\hline 1 & $.727^{\mathrm{a}}$ & .529 & .518 & .20177 & .529 & 26.397 & 5 & 759 & .000 & 1.476 \\
\hline
\end{tabular}

a. Predictors: (Constant), TAN, RES, ASSU, REL, EMP

b. Dependent Variable: Satisfaction

Source: compiled from analysis result of authors

According to estimated model result, $\mathrm{R}$ Square $=0.529$, which means independent variables in the model could explain $52.9 \%$ of overall level of factors effect on customers' satisfaction of State health insurance. That the estimated result is greater than $50 \%$ would be accepted in a model.

Table 9. Coefficient of regression model of factors effecting on customers' satisfaction of State health insurance in Vietnam

Coefficients ${ }^{\mathrm{a}}$

\begin{tabular}{|c|c|c|c|c|c|c|c|c|c|}
\hline \multirow[b]{2}{*}{ Model } & \multicolumn{2}{|c|}{$\begin{array}{l}\text { Unstandardized } \\
\text { Coefficients }\end{array}$} & $\begin{array}{l}\text { Standardized } \\
\text { Coefficients }\end{array}$ & \multirow[b]{2}{*}{$\mathrm{T}$} & \multirow[b]{2}{*}{ Sig. } & \multicolumn{2}{|c|}{$\begin{array}{c}95 \% \text { Confidence } \\
\text { Interval for B }\end{array}$} & \multicolumn{2}{|c|}{$\begin{array}{l}\text { Collinearity } \\
\text { Statistics }\end{array}$} \\
\hline & B & Std. Error & Beta & & & $\begin{array}{l}\text { Lower } \\
\text { Bound }\end{array}$ & $\begin{array}{l}\text { Upper } \\
\text { Bound }\end{array}$ & Tolerance & VIF \\
\hline $1(\mathrm{C})$ & -.479 & .399 & & $1201^{-}$ & .229 & -.900 & -.068 & & \\
\hline ASSU & .275 & .121 & .315 & 2.273 & $.021 * *$ & .135 & .415 & .912 & 1.116 \\
\hline RES & .352 & .115 & .398 & 3.061 & $.043 * *$ & .204 & .500 & .978 & 1.103 \\
\hline REL & .218 & .083 & .247 & 2.627 & $.009 *$ & .087 & .349 & .995 & 1.067 \\
\hline EMP & .187 & .101 & .201 & 1.851 & $.058 * * *$ & .022 & .351 & .926 & 1.135 \\
\hline TAN & .331 & .092 & .374 & 3.598 & $.001 *$ & .167 & .495 & .975 & 1.052 \\
\hline
\end{tabular}

a. Dependent Variable: Satisfaction

Notes: $*, * *, * * *$ are statistically significant at $1 \%, 5 \%$ and $10 \%$ respectively

Source: compiled from analysis result of authors

The table 9 shows that Sig ratio of a slope coefficient which is greater than 0.05 will not be statistically significant at 5\% in significance level. From these results that Sig coefficient of independent variables including ASSU, RES, REL are less than 0.05 , it can be said that these independent variables are statistically significant at $5 \%$ in significance level. The Sig coefficient of TAN variables are less than 0.01 , which means the variable is statistically significant at $1 \%$ in significance level. Significance of EMP variable is 0.058 (less than 0.1 ), which means this variable is statistically significant at $10 \%$ in significance level.

Diminutive order of the impact level of 5 determinants is (1) Responsibility (standardized $\beta$ coefficient is .398), (2) Tangibility (standardized $\beta$ coefficient is .374), (3) Assurance (standardized $\beta$ coefficient is .315), (4) Reliability (standardized $\beta$ coefficient is .247), (5) Empathy (standardized $\beta$ coefficient is .201).

According to the regression model, standardized $\beta$ coefficient which is greater than 0 shows a positive relationship among independent variables in customers' satisfaction of State health insurance. Therefore, the levels of impact of factors on customers' satisfaction of The State Health Insurance are mainly assessed by Responsibility determinant. Meanwhile, Empathy is determinant having lowest impact on customers' satisfaction of The State Health Insurance. 
Table No.10. ANOVA Analysis ANOVA

\begin{tabular}{|ll|r|r|r|r|r|}
\hline Model & Sum of Squares & df & Mean Square & F & Sig. \\
\hline 1 & Regression & 6.362 & 5 & 1.309 & 26.397 & $.000^{\mathrm{b}}$ \\
& Residual & 5.378 & 759 & .047 & & \\
& Total & 11.739 & 764 & & & \\
\hline
\end{tabular}

a. Dependent Variable: Satisfaction

b. Predictors: (Constant), TAN, RES, ASSU, REL, EMP

Source: compiled from analysis result of authors

To test the suitability of the population model, we consider the F-statistics from ANOVA analysis table, Fstatistics $=26.397$, Sig. $=.000$ (less than 0.05$)$, so the linear regression model is appropriate for the data set and can be used.

The table shows that independent variables: Reliability, Assurance, Responsibility, Empathy and Tangibility have great effects on customers' satisfaction of State health insurance in Vietnam. All of the determinants are statistically significant and positively correlative to customers' satisfaction of State health insurance. Coefficients of regression are greater than 0 . Null hypothesis (H0) is rejected; H1, H2, H3, H4 and H5 are accepted. From these results, it can be said that all determinants mentioned above have a positive impact on the impact level of factors on customers' satisfaction of State health insurance in Vietnam.

The meaning of the slope B:

$+\mathrm{B} 1=0.275>0$ : when Assurance variable increases by 1 unit, the average implementation level increases by 0.275 units. The standard regression value of Assurance variable affects $31.5 \%$ on customers' satisfaction of State health insurance.

$+\mathrm{B} 2=0.352>0$ : when Responsibility variable increases by 1 unit, the average implementation level increases by 0.352 units. The standard regression value of Responsibility variables affects $39.8 \%$ on customers' satisfaction of State health insurance.

$+\mathrm{B} 3=0.218>0$ : when Reliability variable increases by 1 unit, the average implementation level increases by 0.218 units. The standard regression value of Reliability variable affects $24.7 \%$ on customers' satisfaction of State health insurance.

$+\mathrm{B} 4=0.187>0$ : when Empathy variable increases by 1 unit, the average implementation level increases by 0.187 units. The standard regression value of Empathy affects $20.1 \%$ on customers' satisfaction of State health insurance. + B5 $=0.331>0$ : when Tangibility variable increases by 1 unit, the average implementation level increases by 0.331 units. The standard regression value of Tangibility variable affects $37.4 \%$ on customers' satisfaction of State health insurance.

The importance of variables which have a great effect on customers' satisfaction of State health insurance in commercial banks in Vietnam is estimated through standardized regression values. The results show that the level of customers' satisfaction of State health insurance is most affected by Responsibility determinant, followed by Tangibility, Assurance, Reliability and Empathy determinant respectively.

\section{Conclusion}

According to analysis result, it is showed that if Responsibility, Tangibility, Assurance, Reliability, Empathy and are improved, customers' satisfaction of Vietnam's State Health Insurance is increasingly ascended. To enhance Responsibility, it is necessary to focus on diversifying of coverage, willingness to support client. To enhance Tangibility, it is necessary to focus on healthcare's infrastructure as well as reimbursement tools and methods. To enhance Assurance, it is needed to concentrate on training professional skills as well as performance acts of staff. To enhance Reliability, it is needed to improve service quality as well as apply technology in administration and governance. About Empathy, it is relating to understanding, attention, convenient from the insurance staff to client. Improving these issues will contribute to enhancing the quality of health insurance services, sustain as well as expand the covering of universal health insurance in Vietnam, reducing the out-of-pocket of population when they use health care services.

\section{References}

Brady, M. K. \& Cronin Jr, J. J. (2001). Some new thoughts on conceptualizing perceived service quality: a hierarchical approach. Journal of Marketing, 65 (3): 34-49.

Comrey, A., \& Lee, H. (1992). A first course in factor analysis. Hillsdale, New York: Erlbaum.

Cronin, J. J. and Taylor, S. A. (1992). Measuring service quality: a reexamination and extension. Journal of Marketing, 56: 55-68.

Dabholkar, P. A., Thorpe, D. I. \& Rentz, J. O. (1996). A measure of service quality for retail stores: scale development and validation. Journal of the Academy of Marketing Science, 24 (1): 3-16. 
Emel, K. Y. (2014). A Review on Dimensions of Service Quality Models. Journal of Marketing Management, 2 (2): $79-93$

Frost, F. A. and Kumar, M. (2000). INTSERVQUAL-an internal adaptation of the GAP model in a large service organisation. Journal of Services Marketing, 14 (5): 358-377.

Geoff, N. (2010). Likert scales, levels of measurement and the "laws" of statistics. Advances in Health Sciences Education, 15 (5): 625-632.

Gerbing, D. W., \& Anderson, J. C. (1988). An updated paradigm for scale development incorporating unidimensionality and its assessment. Journal of marketing research, 25(2), 186-192.

Hair, J.F; Black, W. C; Babin, B.J, Anderson, R. E; Tatham, R. L. (2006). Mutilvariate Data Analysis (6 ${ }^{\text {th }}$ edition). Upper Saddle River, NJ: Prentice Hall.

Hendrickson, A. R., Massey, P. D., \& Cronan, T. P. (1993). On the test-retest reliability of perceived usefulness and perceived ease of use scales. MIS quarterly, 227-230.

Lee Donhee (2016). HEALTHQUAL: a multi-item scale for assessing healthcare service quality. Journal of Service Business, Volume 11(3), pp 491-456.

Likert, Rensis (1932). A Technique for the Measurement of Attitudes. Archives of Psychology, 140 (55).

McGraw, K. O., and Wong, S. P. (1996) Forming Inferences about Some Intraclass Correlation Coefficients. Psychological Methods, 1, p30-46.

Nguyen Thi Nhu Quynh and Neera Dhar (2014). A study of satisfaction among poor patients holding health insurance card with health care services at two district public hospitals in Vietnam. Health and Population Perspectives and Issues 37 (1\&2), 50-56.

Parasuraman, A., Zeithaml, V. A. and Berry, L. L. (1988). SERVQUAL: a multiple-item scale for measuring consumer perceptions of service quality. Journal of Retailing. 64 (1): 12-40.

Toni Lupo (2016). A fuzzy framework to evaluate service quality in the healthcare industry: An empirical case of public hospital service evaluation in Sicily. Applied Soft Computing, 40, 468-478.

Trong, H., \& Chu, N. M. N. (2005). Data Analysis with SPSS research.

Yogesh P. P., Satyanarayana C. T. (2012). Measuring Hospital Service quality a conceptual framework, In International Conference on Humanities, Economics and Geography, Bangkok, Thailand, 17-18 March 2012. 